\title{
Armand Imbert, Adolf Fick, and their tonometry law
}

\begin{abstract}
'The basis of tonometry by applanation, even of tonometry as a whole, is Fick's law, or Imbert-Fick's law, which actually is a much more accurate name'. It is affirmatively cited solely in the ophthalmic and optometric literature, and in patent applications for new tonometers, but as a law of physics underlying clinical practice, it has been challenged both on theoretical grounds and on empirical, evidence-based, data. As the diagnosis and treatment success of glaucoma are primarily determined by tonometry, it seemed profitable to explore in historical context the genesis of this 'law' that was said to be the basis of the method.
\end{abstract}

Eye (2012) 26, 13-16; doi:10.1038/eye.2011.248;

published online 21 October 2011

Keywords: tonometry; Imbert; Fick; glaucoma

\section{Armand Imbert}

The impetus to Imbert's brief article ${ }^{1-5}$ on the advantage of applanation tonometry ${ }^{6}$ was a report, which appeared a few months earlier in the same journal by Maklakoff, ${ }^{7}$ introducing his newly invented tonometer. Imbert's own discussion of the method of tonometry was one of the few not accompanied by a description of a new tonometer invented by its author.

Although a number of ophthalmotonometers have already been constructed, and men of considerable repute in the science engaged in the measure of intraocular tension, yet it does not appear that the theory of the instruments envisioned and the principles on which we must be guided in this sort of research have been established in a very rigorous manner. In our opinion the elasticity of the sclera which plays an important role at the moment an ophthalmotonometer is applied was also neglected.

HH Mark

He then proceeded to show, by a number of simple equations, the relationships between the different parameters, which determine the pressure exerted by liquid inside a globe on its elastic surface, such as the sclera. But, he said, as the value of each of these parameters is hard to measure, the accuracy of the tonometer's pressure reading was doubtful. At that time, pressure in the eye (intra-ocular pressure (IOP)) was measured mostly by the available indentation tonometers applied to the sclera, though until the beginning of the twentieth century, most practitioners, including the noted historian Julius Hirschberg, still preferred digital tonometry.

But it is easier to completely remove the difficulty thus arising by substituting the concave depression (indentation) by a plane depression on the surface of the globe, as is done by $\mathrm{Mr}$ Maklakoff. Indeed, the normal component $\mathrm{N}$ is then cancelled and the equilibrium equation is reduced to $\mathrm{P}=\mathrm{T}$ regardless of the original form of the depressed surface, its state of tension or the value of the intra-ocular pressure.

All forces cancel each other when the application of the tonometer produces a flat surface instead of a concave one, and the reading of the tonometer $(\mathrm{P})$ then equals $(\mathrm{T})$ the IOP. 'In summary, we must abandon the tonometers producing a concave depression (indentation), as not being susceptible to receive a general graduation, and use instruments that produce a flat depression (applanation)'.

Armand Imbert was born in 1850 in Seyneles-Alpes (southeastern corner of France) to a middle-class intellectual family, the father having been a teacher, and then a college professor of mathematics, whose three sons went into medicine. Armand received a doctorate degree in physics in Lyon in 1880 with a thesis titled 'Theoretical and experimental research on the elasticity of rubber' (which may
Department of Ophthalmology, Yale-New Haven Hospital, North Haven, CT, USA

Correspondence: HH Mark, Department of Ophthalmology, Yale-New Haven Hospital, 16 Broadway, North Haven, CT 06473, USA

Tel: + 1203234 2212;

Fax: + 12036511015

E-mail: iimd@aol.com

Received: 3 May 2011 Accepted in revised form: 12 August 2011

Published online: 21 October 2011 
explain his interest in the elasticity of the sclera), and a doctor of medicine in 1883 with a thesis titled 'The interpretation and use of dioptric power and dioptric unit values in ophthalmology'. From 1889 on, he served as chair of medical physics in the Montpellier Medical School, and was chief of the Department of Electrotherapy and Radiography in Saint Eloi Hospital. He was elected corresponding member of the French Academy of Science in $1899 .^{8}$

Imbert made many contributions to various disciplines, most notably to medical and biological physics, occupational medicine, ergonomics, and ophthalmology. He was among the first to introduce $X$-rays to France a couple of months after their discovery by Roentgen, advocated their use in medicine, and with his brother Léon, was the first to report the application of radiotherapy for prostate cancer. His publications on diseases and the welfare of laborers in various trades were perhaps the best since Ramazzini's book of 1700 . In a related area, he published on methods to mediate conflicts between management and labor, and helped carry them out in practice in cooperation with the ministry of labor by setting limits to the daily working hours in general, and to the age of employment of juveniles.

In ophthalmology, in addition to the articles mentioned above, Imbert's books included one on astigmatism, one on the choice of spectacles in relation to variation of accommodation with age, ${ }^{9}$ and on 'The Anomalies of Vision' (1887), with an introduction by Emile Javal (1888). ${ }^{10}$ His contributions to visual optics were incorporated in the French edition of Wundt's voluminous book on Medical Physics. ${ }^{11}$ As part of his general interest in public health, Imbert advocated ocular hygiene for students, and instituted eye examinations in the schools of Montpelier. Among his articles was one on astigmatism in asymmetrical skulls, and one on the causes of permanent amblyopias.

Armand Imbert died in Bordeaux on 6 July 1922. His belongings, furniture, and publications are now in possession of his grandson Lucien, and are open to the public in his thirteenth century restored chateau in Saint-Laurent-des-Batons, 65 miles east of the city (www.sudouest.fr/2010/09/16/le-grand-hommedu-chateau-de-saint-maurice-186271-2080.php.

Accessed 26 October 2010).

\section{Adolf Eugen Fick}

The short paper on a new theoretical method to measure IOP, followed by description of a newly invented tonometer built on these principles, appeared in the prestigious Pflügers Archives of Physiology in 1888, and presented at the Seventh International Congress of
Ophthalmology in Heidelberg that year. 'I believe to have found a method to solve the already oft tackled task of measuring from outside the hydrostatic pressure inside the eyeball' ${ }^{12}$

A bent thread is held tense by forces $P$. When one then presses on it from above with force $Q$, a larger force $Q+q$ is required if equilibrium is desired. The situation is different when the thread is taut straight, then equilibrium will ensue only when the forces $Q$ from above and below are equal, no matter what the tension $P$ is on the thread. Similar circumstances hold for a balloon built of a bendable wall, wherein a certain hydrostatic pressure exists. When a small flat plate $\mathrm{mm}$ is pressed just so that its underside levels with the balloons walls, 'then force $Q$ on the plate's surface is exactly equal to the hydrostatic pressure inside'. (His emphasis).

The author acknowledged at the end of the paper the prior works by Maklakoff and by Imbert, and announced that more details will follow in an inaugural dissertation. Adolf 's son, Rudolf Armin, was then graduating in medicine at Würzburg University, with a forty-page dissertation 'A New Ophthalmotonometer', in which he elaborated on the theory and instrument which his father in Zürich invented. ${ }^{13}$

I turned to my father with the question: How best to measure the intraocular pressure from outside? After a brief reflection he answered that it depends naturally on eliminating the tension of the scleral wall; this happens, by the way, when one presses a piece of sclera flat (plane), then the intraocular pressure inside and the force pressing from outside are in balance! But the question is, if and how the 'plane' pressing is recognized!-I must say, scales fell from my eyes. It is wonderful that nobody recognized this principle and built a tonometer accordingly! ${ }^{14}$

The son described in detail the very specific properties of the globe envisioned in their theory, where the sclera was regarded as capable of being bent, but not stretched: 'As a piece of linen or paper, for instance, may be bent, folded and wrinkled with infinitely small force, whereas it cannot at all, or only insignificantly, be stretched'. Furthermore in the same spirit: 'We may then calmly base our mechanical considerations on a schematic eye of completely spherical form with walls which may be fully bent but not stretched, and allow us to completely disregard the elasticity'. (Emphasis added).

Adolf Fick was born in Kassel on 3 September 1829, the youngest of nine children. He studied medicine in Marburg, where his older brother Franz Ludwig (1813-1858) was a professor of anatomy, and graduated in 1851 with a thesis on astigmatism (Tractatus de errore quodam optico asymmetria bulbi effecto). As a student, 
he also spent some time in Berlin, and with the noted physicist du-Bois-Reymond, published a paper on the dimensions of the blind spot. In 1852, he moved to Zürich where he became a professor of physiology in 1862, and then to Würzburg, with the same position. Fick's name is attached in physics to the laws of diffusion of solutions, and in medicine to the principle of cardiac output.

His approach to physiology was from the perspectives of physics and mathematics, publishing on the mechanism of the joints' articulation, on the power of the muscles, and the source of their energy (sugar, not proteins, as then believed). He invented instruments to measure blood pressure, and the first plathysmograph for recording circulatory phenomena. His main books were on physics in medicine, the physiology of motion and sensation, and on the circulation of the blood. In ophthalmology, aside from the above noted thesis and papers, he wrote on light and color sensations and on the ancillary ocular structures. In Graefe-Saemisches encyclopedic handbook, he authored the thirty-page long chapter on keratoscopy and keratometry (http://de. wikipedia.org/wiki/Adolf Fick. Accessed 26 October 2010).

Adolf's name is sometimes confused with that of his brother Ludwig's son, Adolf Gaston Eugen Fick (1852-1937), whom Adolf adopted when his parents died 5 years after he was born. This Adolf practiced in Zürich, is said to have invented the first contact-lens, had the bacterium Proteus vulgaris named after him, and published a couple of ophthalmology texts. ${ }^{15}$ His cousin, Rudolf Armin (2 February 1866-23 May 1939), who worked with his father on the tonometry problem, was later mainly interested in orthopedics and genetics, and did not contribute anything else to ophthalmology. He was a professor of anatomy, first in Prague, and then in Innsbruck and Berlin.

\section{Comment}

The principal laws that govern pressure and motion in general were articulated by Isaac Newton. To our subject, his third law applies: 'If you press a stone with your finger, the finger is also pressed by the stone' ${ }^{16}$ In tonometry, one would say 'If you press an eye with a tonometer, the tonometer is also pressed by the eye', thus obtaining the value of the pressure in it. Two main factors nevertheless immensely complicate the circumstances in tonometry. First, between the tonometer and the IOP exists a tissue, usually the cornea, whose properties affect the reading. Secondly, the pressure in the eye is caused by a relatively incompressible liquid encased in a fairly spherical body of variable size and walls, which possess variable properties.
The attribution of a tonometry 'law' or principle to Imbert and Fick, as articulated at the start of his article, was first published by Langenhan ${ }^{17}$ in 1904 as part of Landolt's volume on ocular examination methods: 'Imbert and A. Fick have both independent of one another proven that the tension of the wall can be eliminated in a simple manner'. (His emphasis). The logical construction of this 'proven' method, however, presented some difficulties, because its models were hardly analogous to the human eye, and was quickly challenged by Koster, ${ }^{18}$ working in Theodor Leber's laboratory in Heidelberg, and then as professor of normal and pathological anatomy at the Medical School of Utrecht University.

The analogy of the human eye to a thread stretched between two points was obviously somewhat too simple. It was not clear, for instance, what keeps the thread up at the point where it was bent. The analogy to a sphere of inelastic walls did not fare much better:

As a basis for the theory, Mister Rud. Arm. Fick proceeds from the assumption that the eye has a perfectly spherical form and possesses perfectly bendable but unstretchable walls. This assumption in certainly untenable. Of bodies of equal surface area the sphere has the largest volume, it follows that the proposed liquid filled schematic eye with unstretchable walls is not compressible at all, even when the original pressure equaled zero. ${ }^{18}$

When a spherical rubber balloon filled with water is pressed, it losses its spherical form, and its volume must diminish, either by letting out some water or else the elastic walls must stretch. However, when these walls are made of stiff material that cannot stretch, such as paper or aluminum foil, the balloon is subject only to infinitesimal deformation, and therefore cannot be indented or applanated to any measurable degree whatsoever, even when the interior pressure is zero. This is not only an evidence-based law of physics, but a geometrically axiomatic fact. The eminent Leber ${ }^{19}$ in his chapter 'The Tonometry of the Eye' echoed Koster's objections to Fick's theory, emphasizing that 'The necessary external pressure (tonometric) is naturally dependent on the elasticity and flexibility of the ocular coats, which are not sufficiently known and are not the same in different cases'.

In connection with his newly invented tonometer, Goldmann ${ }^{1}$ adopted the applanation theory with its presuppositions: 'Imbert-Fick's law (sic) presupposes that the membrane is without thickness and without rigidity, and that no other forces interfere'. And further: 'First we shall examine two concentric membranes forming a sphere, practically without any extensibility'. It was again pointed out at that time that these 
presuppositions at the foundation of the so-called Imbert-Fick law were untenable, and hence, the law itself. ${ }^{20}$ Pressure measurements obtained $a b$ externo by any tonometer whatsoever are always only approximations, because they depend on a myriad of mostly unknown different parameters of the individual globe, such as corneal thickness ${ }^{21}$ and curvature, ${ }^{22,23}$ axial length, ${ }^{24}$ or corneal and scleral elasticity, leaving a large room for clinical judgment in the diagnosis and followup of glaucoma. To replace tonometry, one may insert a manometric probe, perhaps diamond tipped, into the anterior chamber, similar to the procedure in spinal fluid pressure measurements. Or else place inside the eye a pressure sensitive device, which transmits its readings to the outside.

\section{Conflict of interest}

The author declares no conflict of interest.

\section{References}

1 Goldmann H. Applanation Tonometry. In: Transact. 2nd Glaucoma Conference. J Macy Jr Foundation: New York, 1957, pp 167-220.

2 Goldmann H, Schmidt Th. Über applanationstonometrie. Ophthalmologica 1957; 134: 221-242.

3 Yanoff M, Duker JS. Ophthalmology. 3rd ed. Mosby/Eslevier: New York, 2009, p 1118.

4 Grehn F, Stamoer R. Glaucoma. Springer: Berlin, 2006, p 48.

5 Goldmann H. Un Nouveau tonometre d'applanation. Bull Soc Franc Ophthalmol 1955; 67: 474-478.

6 Imbert A. Théorie des ophthalmotonomètres. Arch d'ophthalmol 1885; 5: 358-363.
7 Maklakoff AN. L'ophthalmotonométrie. Arch d'ophthalmol 1885; 5: 159-165.

8 Le Bianic T, Vatin F. Armand Imbert (1850-1922), la science du travail et la paix sociale. Travail et Emploi. Publisher: Documentation Francaise: Aubervilliers, 2007; 111: 7-19.

9 Albert DM, Norton WD, Hurtes R. Source Book of Ophthalmology. Blackwell: Cambridge, MA, 1995, pp 167.

10 Imbert A. Anomalies de la vision. Baillière: Paris, 1889.

11 Wundt WM, Imbert A, Monoyer F. Traité elementaire physique medicale. Baillière: Paris, 1884.

12 Fick A. Ueber Messung des Druckes im Auge. Arch ges Physiol 1887; 42: 86-90.

13 Fick RA. Ein neues Ophthalmotonometer. Stahel University Verlag: Würzburg, 1888.

14 Markiewitz HH. Notiz aus der Vergangenheit (Tonometrie). Klin Montbl Aug 1960; 136: 859-860.

15 Lebensohn JE. An Anthology of Ophthalmic Classics. Williams \& Wilkins: Baltimore, MD, 1969, pp 116-120.

16 Newton I. Principia. University of California Press: Berkeley, CA, 1966, p 13.

17 Langenhan F. Ophthalmotonometrie. In: Graefe-Saemisch Handbuch der Gesamten Augenheilkunde Vol 4(1). Wm Engelman: Leipzig, 1904, p 613.

18 Koster W. Beiträge zur Tonometrie und Manometrie des Auges. Graefe's Arch Ophthalmol 1895; 42: 113-158.

19 Leber Th. Die Tonometrie des Auges. In: Graefe-Saemisch Handbuch der Gesamten Augenheilkunde Vol 2(2). Wm Engelman: Leipzig, 1908, pp 314-320.

20 Markiewitz HH. The so-called Imbert-Fick Law (letter). Arch Ophthalmol. 1960; 64: 159.

21 Ehlers N, Bramsen T, Sperling S. Applanation tonometry and central corneal thickness. Acta Ophthalmol 1975; 53: 34-43.

22 Mark HH. Corneal curvature in applanation tonometry. Am J Ophthalmol 1973; 76: 223.

23 Mark HH. Corneal stigmatism in applanation tonometry. Eye 2003; 17: 617-618.

24 Mark HH. Axial length in applanation tonometry. J Cataract Refractive Surg 2002; 28: 504. 